\title{
Lexicografia și istoria culturii (Cazul Dicționarului român-latin al lui Teodor Corbea)
}

\author{
Alin-Mihai Gherman * \\ Facultatea de Istorie și Filologie, Universitatea „1 Decembrie 1918”, Str. Unirii 15-17, 510009 Alba Iulia, România
}

\section{Despre articol}

Istoric:

Primit 17 septembrie 2021

Acceptat 6 octombrie 2021

Publicat 12 decembrie 2021

Cuvinte-cheie:

filologie

editarea textelor

documente vechi

\begin{abstract}
Rezumat
Studiul își propune să sublinieze dimensiunile culturale ale lexicografiei, atît prin revelarea conținutului cultural al lucrărilor lexicografice și al orizontului cultural al autorului, cît și prin căutarea unei motivații precise culturale a dicționarelor. Un exercițiu aparte este făcut asupra Dicţionarului latin-român al lui Teodor Corbea, redactat între anii 1691-1702. Se subliniază caracterul lui enciclopedic şi relațiile cu cultura greco-romană. De asemenea, se analizează paralelismele latino-române și reflexele conștiinței romanității limbii române.
\end{abstract}

\section{Introducere}

Văzută ca o parte mai puțin spectaculoasă a istoriei lingvisticii, istoria lexicografiei nu s-a bucurat de un interes special din partea specialiștilor. Dincolo de acuratețea lor, puținele încercări de redactare ale lexicografiei constau, în marea lor majoritate, în înșiruirea lucrărilor în sine, în evocarea dimensiunilor acestora, a menţionării deficiențelor fiecăreia sau a unui grup dintre ele și a posterității individuale sau a grupului respectiv de dicționare.

1.1. În cazul lexicografiei românești, dincolo de caracterul concis propus prin însuși titlul cărţii, o lucrare meritorie precum Schiță de istorie a lexicografiei românești (Seche, 1966) explică în prea mică măsură contextul cultural și motivele redactării respectivelor lucrări, dovedindu-se mai curînd un fel de „Guiness Book” în domeniul lexicografiei autohtone, vorbind, de exemplu, despre primul dicționar bilingv germanromân, dar neîncercînd să descifreze motivele redactării lui. Fapt foarte important, căci, în principiu, redactarea unei lucrări lexicografice presupune un volum considerabil de muncă și oferă o satisfacție considerabil mai mică autorilor - care, nu în puține cazuri în cadrul literaturii noastre vechi, rămîn anonimisau este atribuită unui ultim copist care s-a semnat. Sau, în cazul culturii noastre moderne, cine amintește de Florian Aaron sau Georges Hill, coautori ai cunoscutului Vocabular franțezo-românesc după cea din urmă ediţie a dicţionarului de Academia Franțozească, tom. 1-2 (Vocab. 1840-1841), cunoscut îndeobște doar sub numele lui Petrache Poenaru, care, în calitatea sa de director la Colegiul „Sfîntul Sava”, s-a semnat primul? Sau de cîte ori este amintit și meritul mult mai cunoscut al lui George Barițiu, care a contribuit la redactarea celui de al doilea volum al primului dicționar academic al limbii române realizat de August Treboniu Laurian și Ioan Massim?

\section{Lexicografia bilingvă românească veche}

Reluînd afirmaţia lui Henricus Stephanus (Henri Estienne) în celebrul Thesaurus grace lingue (TLG), conform căreia munca la redactarea unui dicționar este mai grea decît a celor care vîslesc în galere, sîntem convinși că, în ansamblul ei dar și în fiecare lucrare în parte, trebuie căutată motivația acestei munci în aparență fastidioase. Categoric că nici cîștigul material și nici recunoașterea publică nu au motivat acest

*Adresă de corespondență: diortositor@gmail.com. 
Alin-Mihai Gherman

efort. În cazul lexicografiei bilingve, cel puțin, cauza trebuie căutată în nevoia de accces la o cultură străină, iar în cazul dicționarelor monolingve, în motivări mult mai subtile legate de dezvoltarea conștiinței naționale și de interesul pentru popor. Atît contextul elaborării unei lucrări lexicografice, care niciodată nu este incidental și trebuie deslușit, cît și orizontul cultural oglindit în lucrarea respectivă trebuie privite în legăturile lor cu istoria culturii. Pentru a ne susține acest punct de vedere, vom evoca din această perspectivă cîteva momente din dezvoltarea lexicografiei românești, contextul istoric al acestora și motivația care a dus la redactarea unor lucrări.

2.1. Lexicografia slavo-română, care s-a manifestat în a doua jumătate a secolului al XVII-lea și în prima jumătate a secolului următor, este legată de traducerea textelor liturgice în limba română și, privind conținutul glosarelor slavo-române, poate şi mai mult, de traducerea masivă a documentelor de proprietate slavone, care era practicată curent în acest interval.

2.2. Cele două lucrări lexicografice redactate în Țara Hațegului și estul Banatului în a doua jumătate a secolului al XVII-lea, Anonimus caransebesiensis și Lexicon Marsilianum, privite îndeobște ca niște „accidente" sau niște curiozități ale literaturii noastre vechi, trebuie înțelese ca reprezentînd un aspect coerent al fenomenului de integrare a unui grup de români liberi care trăiau în mediul urban al Caransebeșului, Lugojului sau Hațegului în structurile și cultura principatului Transilvaniei (vezi Gherman, 2019).

2.3. La fel, lexicografia Școlii Ardelene, în care numărul dicționarelor și glosarelor în care limba latină este folosită este majoritar, trebuie înțeleasă nu numai din perspectiva general culturală-limba latină era încă o limbă a culturii europene în general, fiind, pînă spre sfîrșitul secolului al XVIII-lea, și limba unificatoare a administrației multietnicului Imperiu Habsburgic — ci și din cea a programului politic al mișcării, pentru care dovedirea romanității poporului și, implicit, a latinității limbii era un mijloc de argumentare a necesității acordării pentru români a acelorași drepturi și privilegii pe care le aveau, conform legislației medievale încă respectate în principat, celelalte națiuni politice (ungurii, sașii și secuii), lexicografia devenind pentru cărturarii români transilvăneni o armă politică ${ }^{1}$.

2.4. Prelungirea acestei perspective a fost normală pentru doi români ardeleni, Alexandru Treboniu Laurian și Ioan Massim, în situația în care lupta națională a românilor din Transilvania era o continuare logică a celei susţinute de generația Supplex-ului în realizarea primului dicționar al limbii române patronat de Academia Română. Dincolo de munți, însă, programul politic al ardelenilor nu era valabil și nu spunea mare lucru nici cărturarilor erudiți, precum Alexandru Odobescu sau Bogdan Petriceicu Hasdeu, așa că neînțelegerile care au urmat publicării lucrării țin mai mult de lipsa de comprehensiune decît de scăderile acestei lucrări.

2.5. Un ultim exemplu: Ienăchiță Văcărescu a realizat două dicționare, unul german-român și altul romângerman (rămase în manuscris şi care, după părerea noastră, merită o viitoare editare), în care, în mod insolit, lexicul german este transcris fonetic cu slove chirilice. Explicația acestei curiozități ne-o poate oferi conjunctura politică a celei de a doua jumătăţi a secolului al XVIII-lea, Oltenia fiind ocupată pentru o perioadă îndelungată de austrieci. Cele două lucrări aveau, cu precizie, o destinație practică, pentru a înlesni comunicarea cu vremelnicii ocupanți.

\section{Dicționarul latin-român al lui Teodor Corbea}

În cazul literaturii românești vechi și al istoriei lexicografiei noastre, Dicționarul latin-român al lui Teodor Corbea $^{2}$ (intitulat de autor Dictiones latina cum valachica interpretatione) ocupă un loc special prin caracterul său, el fiind cea mai amplă lucrare lexicografică realizată în limba română pînă în a doua jumătate a

\footnotetext{
${ }^{1}$ De observat că glosarul, dialogurile și cuvintele folosite pentru ilustrarea structurii limbii române în Elementa lingue daco-romane sive Valachice, publicată de Samuil Micu și Gheorghe Șincai la Viena, în 1780, cuprind aproape în exclusivitate cuvinte de origine latină. Observația este valabilă și pentru a doua ediție, apărută doar sub numele lui Gheorghe Șincai.

${ }^{2}$ Publicat de subsemnatul în 2001 la editura Clusium din Cluj-Napoca. O nouă ediție, însoțită de indicele lexicului românesc și de facsimilele pe CD ale manuscrisului este în faza de finalizare.
} 
secolului al XIX-lea și conținînd, alături de Biblia de la București (1688), cel mai amplu inventar lexical al unui text vechi.

3.1. Dicționarul lui Corbea este manuscrisul autograf al autorului, dar nu este datat. La sfîrșitul lui se află următoarea mențiune: „La tălmăcirea acestuiu lixicon ostenitu-s-au din plata părintelui Mitrofan, episcopul de Buzău, Todor Corbea, sîn iermonah Ioasaf din Braşov”. În lipsa unei datări precise a scrierii dicționarului, luînd în considerare anii în care Mitrofan a fost în scaunul Buzăului, lucrarea lui Teodor Corbea poate fi cu siguranță datată între anii 1691-1702. Numărul mare de călătorii efectuate de Teodor Corbea în Rusia și Transilvania, începînd cu 1698, nu ar fi permis realizarea unei lucrări de o asemenea amploare, ceea ne face să limităm și mai mult timpul în care a fost redactat dicționarul la prima parte a acestui interval.

3.2. Episcopul Mitrofan este una dintre cele mai complexe personalități ale culturii noastre din a doua jumătate a secolului al XVII-lea şi de la începutul celui următor: fost colaborator apropiat, în calitate de episcop de Huşi, al Mitropolitului Dosoftei, refugiat după al doilea exil al acestuia în Țara Românească, Mitrofan a fost diortositorul Bibliei de la Bucureşti şi al altor cărți tipărite în primii ani ai domniei lui Constantin Brîncoveanu. Lui i se datorează amestecul dialectal al formelor muntenești şi moldoveneşti din prima imprimare integrală a Sfintei Scripturi în limba română. Ulterior, în calitate de episcop al Buzăului (1691-1702), unde înființează şi o tipografie, tipărește lucrări importante pentru biserică, dar, mai ales, pentru susținerea spiritului pravoslavnic: prima traducere românească a Pravoslavnicii mărturisiri (datorată credinciosului colaborator şi cronicar oficial al lui Brîncoveanu, Radu Greceanu, care mai înainte fusese, împreună cu fratele său, şi colaborator la definitivarea pentru tipar a textului Bibliei), prima tipărire a Mineiului (1698, în care-fapt nerelevat pînă acum-relua şi texte din Viața şi petreacerea svinţilor a mitropolitului Dosoftei), un Molitvenic slav şi românesc (1699), Octoih ce să zice osmoglasnic (1700), Triod, ce să zice tripeasneță (1700), Euhologhion, adecă molitvenic slav şi românesc (1701), Penticostariu slav şi românesc (1701), Psaltire (1701), Invățătura preoților pre scurt de şapte taine (1702), Sfinta şi dumnezeiasca liturghie (1702). Cel puțin unele dintre versurile la stemă ale acestor tipărituri şi unele vieți de sfinți din Minei pot fi atribuite, după formele de limbă sau după stilul versificației, lui Teodor Corbea. Solicitarea lui de către Mitrofan pentru alcătuirea acestui dicționar era întemeiată de buna cunoaștere a limbii latine, pentru care fusese numit „sicritariu de taină” al lui Constantin Brîncoveanu și purtase în numele voievodului, al Cantacuzinilor și al său personal o amplă corespondență latină cu autorități habsburgice sau cu voievodul Transilvaniei Francisc Rákóczi al II-lea (vezi Pippidi, 2005).

3.3. Originar din Șcheii Brașovului, fiu al unuia dintre preoții de la biserica „Sfîntul Nicolae”, de acolo și frate al lui David, cunoscut diplomat al epocii, Teodor Corbea era un bun cunoscător de latină, slavonă și maghiară, primele două limbi aprofundîndu-le probabil la Academia din Kiev. Buna cunoaștere a latinei l-a recomandat ca secretar al voievodului Constantin Brîncoveanu, dar şi ca un apropiat colaborator al Cantacuzinilor. După fuga sa în Rusia, în urma campaniei din 1711 a lui Petru cel Mare în Moldova și Țara Românească, a fost și un apropiat colaborator al țarului Rusiei. El nu se considera pe el însuși a fi autor al dicționarului, ci doar traducător, după cum se dovedește din articolul Theodorus din dicționar: „Theodorus, g.m. ${ }^{3}$ nume de bărbați de obşte; item: numele acestui de pă urmă, care această carte de pă latinie şi ungurie o au tălmăcit rumîneaşte”. Sursa dicţionarului său o mărturisește el însuși: este vorba de a treia ediție a dicționarului latin-maghiar al lui Albert Szenczi Molnár (vezi DUL) (care a folosit, la rîndul său, Dictionarium latino-germanicum al lui Petrus Dasypodius și Petrus Cholinus, una dintre multele ediții ale lui Calepinus sau Dictionarium latino-germanicum, al lui Johannes Frisius), din care păstrează articole ca: „Itorsium, g.n. orăşăl în țînutul domnilor norimbergheani, în care acest noriberghean svat cinsteş bogată academie au zidit în numărul anilor 1575, unde acest Lixicon l-au scris Albertus Molnar în numărul anilor 1603” sau: „Argentina, g.f. et Argentoratum tare oraş al Țărei Nemțeşti lîngă apa Rhenus, în

\footnotetext{
${ }^{3}$ Dicționarul lui Corbea, fiind scris cu caractere latine (în mod normal, în partea sa latină), dar incidental şi în partea românească (scrisă în cea mai mare parte a ei cu chirilice), am optat pentru transcrierea tuturor caracterelor latine, oriunde se află ele în text, cu caractere grase (bold).
} 
țînutul Alsaţiei. Acolo ca acela înalt turn iaste şi bisearecă înfrîmşețată, cît în Europa altă bisearică sau turn aseamine acestora nu iaste. Iaste iarăş acolo o academie vestită, în care de demult mulți înțelepți oameni s-au învăţat, unde şi eu, care această carte am scris (adecă Albert Molnaru) trei ani şi jumătate am lăcuit în vreamea copilăriei”. Nu este, însă, o traducere mecanică a dicționarului maghiar, Teodor Corbea eliminînd multe articole pe care le considera, probabil, ca fiind inutile, scurtînd altele și, fapt semnificativ, adăugînd unele articole în lista lui Szenczi Molnár, dîndu-le și echivalentul românesc.

\section{Dimensiunea enciclopedică a dicționarului}

Confruntarea listelor de cuvinte latine ale dicționarului lui Szenczi şi al lui Corbea ne arată, însă, că el a avut o atitudine creatoare, atît prin eliminarea unor articole, cît şi prin selectarea, în cadrul articolelor, a sensurilor care să fie echivalate în româneşte, dar și adăugînd el însuși articole pe care le-a considerat necesare în urma activității sale de secretar de limbă latină al lui Constantin Brîncoveanu sau al Cantacuzinilor.

4.1. Păstrarea unui număr considerabil de articole cu referire la cultura antică greco-romană dovedește aderența lui Teodor Corbea la curentul de modernizare a culturii noastre cunoscut sub numele de „umanism românesc", alăturîndu-1, cu siguranță, contribuțiilor stolnicului Constantin Cantacuzino și chiar celor ale lui Dimitrie Cantemir, căci dicționarul lui primește, alături de trăsătura de dicționar bilingv, și o pronunțată dimensiune enciclopedică.

4.2. La Teodor Corbea, pentru prima dată în cultura română, Roma martirajelor (văzută pînă la el, din punct de vedere creştin, doar ca un nou Babilon apocaliptic, iar din punctul de vedere al Bisericii Răsăritene, ca un centru al schismei religioase) devine oraşul glorios al culturii antice. $\mathrm{O}$ asemenea cercetare nu se poate face decît analizînd textele, iar Dicționarul latin-român al lui Teodor Corbea ni se pare ideal din acest punct de vedere. O confruntare a celor două imagini ale Cetății Eterne a produs și în cultura occidentală o dezbatere puternică în perioada Umanismului și a Renaşterii, dar şi în epoca care i-a urmat acesteia.

4.3. De la bun început trebuie să observăm că referirile la creştinism şi la martirajele romane sînt extrem de puține ${ }^{4}$ : „Bibiana, g.f. o fată creştină rimleancă, care supt Iuliian s-au omorît pentru căce că au ajutat tătîni-său să îngroape trupurile ceale moarte ale creştinilor”, „Chrysantus, g.m. un voinic de la Alixandriia, care la Roma pentru leagea credinței creştineşti s-au omorît”, „Betlehem, g.f. [n.n.: recte: Bethleheem] oraş al Iudeii, de-acolo pînă în Ierusalim 7 mile de loc, în care Domnul nostru Isus Hristos s-au născut”, „Bethsames, g.f. oraş al Galileei în care Domnul nostru Isus Hristos, precum spun scripturile, multe minuni au făcut”, „Origenes, g.m. numele unui dascal creştin” etc. Împărații prigonitori ai creștinilor nu sînt priviți negativ, aşa cum sîntem obişnuiţi din literatura hagiografică: „Decius, g.m. nume al unui rimlean”, „Julianus, g.m. numele unui împărat rimlenesc” etc. În cazul lui Nero, imaginea negativă poate fi extrasă mai mult din textele istoricilor antici decît din viețile sfinților: „Nero, -onis, g.m. numele unui împărat rimlean nemilostiv".

4.4. Nici referirile negative la păgînismul Antichităţii nu sînt foarte dese: „Arsenotheles, g.m. pl. dumnezăi au fost pre carii i-au socotit păgînii a avea năravuri şi bărbăteşti şi muiereşti”, „Comus, g.m. dumnezău ${ }^{5}$ în zîlele păgînilor al nuntelor de noapte şi al jocurilor”, „diffareatio, g.f. jîrtvă au fost la păgîni spre despărțîrea casătoriei”, „ethnicus, -a, -um păgîn, -că”, „Portunu, g.m. dumnezăul vînslarilor şi al vadurilor au fost întru păgînime”, „Saturnus, g.m. una dintre 7 planite; item: tatăl lui Iupiter, Iunei, al lui Neptunus şi Pluto, pre care în păgînime l-au țînut dumnezău”, „Tutanus, g.m. dumnezău au fost între păgînimea rimlenească, pre care în nevoile ceale prea mari l-au chiemat într-ajutori”, „Vertumnus, g.m. dumnezău

\footnotetext{
${ }^{4}$ Acest fapt poate fi explicat şi prin sursa dicționarului lui Corbea: fiind reformat (calvin), Szenczi Molnár a făcut şi el în mare parte abstracție de viețile sfinților şi de martirajele din prima epocă a creştinătății.

${ }^{5}$ De menționat faptul că Teodor Corbea nu a avut cuvinte diferite pentru a denumi zeii Antichității şi Dumnezeul creştinilor, folosind pentru ambele noțiuni acelaşi cuvînt. Pentru „zeiță” foloseşte termenul, insolit pînă acum în limba română: dumnezăoaie.
} 
au fost întru păgînime al învîrtirei, al întoarcerei”, „Vitunus, g.m. dumnezău păgînesc de demult au fost, pre care l-au socotit dătători de viiață”.

4.5. Orizontul geografic al Dicţionarului român-latin al lui Corbea se opreşte la cel al Antichității, vorbind doar despre cele trei continente cunoscute atunci, în vechime (Asia, Africa şi Europa), avînd un evident caracter eurocentrist: „Africa, g.f. o parte dintre trei părți a ocolului pămîntului”, „Aphrica, g.f. a treia parte a acestui pămînt”, „Asia, g.f. una dintre ceaste 3 părţi ale lumiei”; o uşoară ezitare, ca urmare a unor vagi cunoștințe despre noile descoperiri geografice, o găsim în definirea Europei: „Europa, g.f. a treaea sau a patra parte a ceștii lumi, în care iaste Țara Nemțască, Țara Ungurească și Țara Italiei, de la Nemțasca Mare pînă la Marea-din-Mijlocul-Pămîntului și pînă la apa Tanaisului”. Din aceeași perspectivă eurocentristă, datorată culturii antice, nu surprinde imaginea unei Italii mult mai bine cunoscute decît alte regiuni periferice ale continentului; centrul Italiei este Roma, lucru mărturisit şi prin definiţia: „Italia, g.f. Italiia, în Europa între Marea Adriaticum şi Tyrhenum, care are oraş mare pă Roma”. Aceasta devine un punct de referință esențial, apropierea (sau distanța) de ea fiind foarte importantă .

4.6. Istoria romană este, de asemenea, foarte bine cunoscută ${ }^{7}$, dar adevărata Antichitate este pentru Teodor Corbea cea a culturii. El cunoaşte numele marilor scriitori latini: Cicero ${ }^{8}$, Horațiu $^{9}$, Ovidius ${ }^{10}$, Iuvenal ${ }^{11}$, Lucrețiu $^{12}$, Titus Livius ${ }^{13}$ etc. Despre Vergilius şi cărțile sale ştie şi mai multe ${ }^{14}$, iar latina ciceroniană (cu citarea expresă a formelor de limbă aflate în opera lui) este un reper la care revine în multe rînduri.

4.7. Dincolo de lumea culturii latine, cel mai citat scriitor este, cu siguranță, Homer („Homerus, g.m. numele unui petic elin vestit şi înţelept”), căruia îi numeşte şi două dintre epopeile sale, Iliada ${ }^{15}$ şi $B a-$ trachomyomachia, dicționarul lui Corbea fiind plin de evenimente şi personaje din Iliada şi Odiseea ${ }^{16}$,

${ }^{6}$ „Beletra, g.f. oraş italienesc, nu departe de la Roma”, „Bovilliæ, g.f. pl. oraş aproape de Roma”, „Præneste, g.f. oraş au fost italienescu, nu departe de Roma”, „Tybur, -ris, g.m. oraş italienesc aproape de Roma”, „Ostia, g.f. oraş italienesc dincolo de Roma, unde cură Tiberisul în mare”. Roma însăşi este foarte bine cunoscută lui Corbea: „Æquimelium, g.n. numele unui loc la Roma”, „Agrosus, g.m. dealul pă care acmu zace Roma”, „Argiletum, g.n. un loc în Roma nu dăparte de la Palațium”, „Buthrotum, g.n. loc obăgit la Roma”, „Carmentalis, -e, g.f. [n.n.: recte: Carmentalia] nume a unii porț de la Roma”, „Carseoli, g.m. pl. sat de la Roma”, „circus, g.m. [...] în Roma o zidire mare rotească, loc de privirea jocurilor”, „Cispius, g.m. un munte la Roma”, „Coelium, g.m. un munte la Roma, vide: Cæeelius”, „Fontinalis, g.f. nume al porței de la Roma care cu alt nume să zîce Capena”, „Fori, -orum [...] loc de privit au fost în Roma”.

7 „Ariobarzanes, g.m. nume al unui împărat de la Machidoniia, care romanilor au fost priiatin bun”, „Asinius, g.m. orator roman, frate lui Avgust”, „Atratimus, g.m. procator de la Roma au fost”, „Cærsar, g.m. nume al cîtorva romani de pre carii pre toț împărații rimleneşti îi număsc Chiesar”, „Catilina, g.m. un domn de la Roma viclean, care au fost nevoitori spre aducerea răului rimlenescu”, „centumviri, g.m. pl. o sută de oameni județi de la Roma”, „Cethegus, g.m. pîrgari de la Roma”, „Claudia, g.f. o fămeaie rimleancă; iarăş: o seminție vestită la Roma”, „Claudianus, g.m. un poetic alixandrinean; iarăş: un împărat de la Roma”, „decemviri, g.m. pl. zeace oameni mari, boiari, care au îndereptat Roma”, „dictator, g.m. crai prea mare au fost în Roma, pre carele în vreame răscolită spre aceaea l-au ales ca toți de dînsul să spînzure”, „Gabinus, -i, g.m. un om mare de la Roma”, „Galba, g.f. [...] numele unui om de la Roma”, „Gracchus, g.m. nume al unui pîrgari de la Roma”.

${ }^{8}$ „Cicero un vestit şi mărit boiar de la Roma şi înțelept înfrîmşețat vorovitori”.

${ }^{9}$ „Horatius, g.m. un poetic liricusean şi satirisean”.

${ }^{10}$ „Ovidius, - -i, g.m. numele unui poetic vestit”.

${ }^{11}$ "Juvenalis, g.m. numele unui poetic satiric".

${ }^{12}$ „Lucretius, g.m. un poetic de demult care s-au născut după Țițero la al doisprăzeacelea an”.

${ }^{13}$ „Livius, g.m. un istoriceari vestit, care de lucrurile făcute rimleneşti cu împodobire au scris”.

${ }^{14}$ „Actor, g.m. numele al unui om în Virghilius”, „Acutia, g.f. muiarea lui Virghilius”, „Alcanor, g.m. nume al unui om de care Virghilius pomeneaşte”, „Almon, g.f. [...] un nume de păstori la Virghilius”, „Alphesibæus, g.m. nume al unui păstori în Virghilius”, „Alsus, g.m. un nume de păstori în Virghilius”, „Amaryllis, -idis, g.f. nume al unei mojice în cartea lui Virghilius”, „Andes, g.m. pl. un sat lîngă Mantuanal [sic!], în care Virghilius s-au născut”, „Anthores, g.m. nume al unui om în Virghilius”, „Bavius, g.m. un poetic neînvațat, pizmaş lui Virgilius”, „Bianor, g.m. nume al unui om in Virgilio”, „Choroebus, g.m. [...] numele unui copil nebunatec in Virgilio”, „Corydon, g.m. un păstori în Theocritus şi în Virghilius”, „Damoctas, g.m. nume al unui păstori la Virghilius”, „Didymaon, g.m. un faur vestit de care pomeneaşte Virghilius”.

${ }^{15}$ „Ilias, -dis, g.f. cartea lui Homerus de piiarderea Troadei”.

${ }^{16}$ „Achilles, g.m. fiiul lui Oeleus, care au fost hodnogi în războiul Troadei”, „Æantium, g.n. oraş al Troadei”, „Agastrophos, g.m. fiul lui Peon şi, în războiul de la Troada, mare viteazu”, „Ajax, -cis, g.m. numele la doi greci viteazi în războiul Troadei, polecra unuia Telatonius, al altuia Oilesus”, „Alcander, g.m. unul dintre soțîi lițieneşti ai lui Sarpedon, pre 
dar amintind şi de „Batrachonyomarchia, război de broaşte şi de şoareci, adecă războiul broaştelor cu al şoarecilor, de care au scris Homerus”.

4.8. Mitologia greco-latină este şi ea copios prezentă în textul lui Corbea. Interesant este faptul că aceasta nu este pentru scriitorul braşovean o dimensiune a păgînismului, ci a culturii literare şi a imaginaţiei poetice, înregistrînd datele din perspectiva florilegiilor renascentiste ${ }^{17}$. Distanțarea de Antichitate, care rămîne un punct de reper esențial din punct de vedere cultural, se face la Corbea prea puțin din perspectiva conflictului creștinism-păgînism, ci din punctul de vedere al unui spirit modern, care constată că trăiește o altă epocă decît cea revolută, în care au trăit „bătrînii” sau „cei de demult” ${ }^{18}$; „cei de demult”, „bătrînii” şi „poeticii” reprezentau un univers închis, o altă civilizaţie şi o altă lume, astfel încît nu se pune problema unui conflict între creştinism şi lumea Antichităţii păgîne. De asemenea, sub aceleaşi expresie se pot denumi şi popoare dispărute din istorie sau obiecte al căror uz se cunoaşte doar din relatări antice ${ }^{19}$.

Observăm că pentru Corbea cele două Rome, una simbolizînd lumea creştină şi alta Antichitatea, nu se aflau în conflict (Gherman, 2001) pentru simplul motiv că în mentalitatea sa cele două aspecte ale

carele în războiul Troadei Ulises l-au omorît”, „Alethes, g.m. nume al unui om din Troada”, „Andromache, g.f. muiarea lui Hector de la Troada”, „Antenor, g.m. numele al unui om mare de la Troada”, ,antepilani înainte umblători aleş viteaji au fost la războiul Troadei”, „Anthemion, g.m. tatăl lui Sişocus de la Troada”, „Antilochus, g.m. fiiul lui Nestor în războiul Troadei, de la Memnos s-au omorît”, „Astynous, g.m. hearțeg troadean pre carele Diomedes l-au tăiat”, „Aulis, -dis, g.f. oraş elinesc; unde semințiile care au mărs supt Troada s-au adunat dempreună”, „Berirthrus, g.f. un oraş de la Troada”, „Cajeta, g.f. nume al unii muieri de la Troada”, „Berytis oraş care să ţîne de Troada”, „Dardanus, g.m. fiiul lui Iupiter şi al Electrei de pre care Dardania apoi s-au numit Troada”, „Diomedes, g.m. craiul Etoliei şi în războiul Troadei hătnogi mare al grecilor sau elinilor”, „Epeus, g.m. numele aceluia care au făcut calul cela mare de lemn de la Troada”, „Glaucus, g.m. fiiul lui Hippolocus în războiul Troadei”, „Helena, g.f. fata lui Tindarus, muiarea lui Menelau, pentru a căriia frîmseațe s-au pierdut Troada”, „Adamastus, g.m. un ithacliian soț lui Ulises”, „Calypso, g.f. fata lui Oțeian la carea au fost Ulises”, „Elpenor, g.m. soț de călătorie al lui Ulises pre carele Țirțe cu cîteva [sic!] cu dîns l-au şimbat în porc”, „Ithaca, g.f. ostrov la Marea Ionium în care au domnit Ulises”, „Polyphenus, -i, g.m. un uriiaş care au avut numai un ochi şi şi acela i l-au scos Ulises”, „Telegonus, g.m. un fii al lui Ulises de la T,irțe”, „Telemachus, g.m. fiul lui Ulises de la Penelope”, „Theoclymenus, g.m. un spuitori de ceale viitoare, care au gîcit Penelopei venirea bărbatului său, a lui Ulises”, „Scylla, g.f. [...] fata lui Forcus, care (precum scriu poeticii) s-au şimbat în stîncă de piiatră de mare sau în jivină cu formă ciudată care aşa urlă ca cîinele” etc.

${ }^{17}$ „Atlas, -antis, g.m. un munte înalt în Mauritaniia, iară la poetici, un uriiaş mare care țîne ceriul în spate”, „Averna, g.n. pl. un aleşteu în țînutul Campaniei, pre care i-au zîs poeticii a fi poarta iadului”, „Dindymus, g.m. sing. in plur. dindima vîrfurile ceale înalte a munților de la Frighiia; la poetici s-au svințit mumînilor dumnezăilor”, „Europa, -x, g.f. idem, item: fata lui Oțeanus după scrisoarea poeticilor”, „Geryon, g.m. crai şpaniolesc au fost pre care l-au omorît Hercules, care au avut trei capete, precum scriu poeticii”, „Hymen, g.m. dumnezăul nuntelor după scrisorile poeticilor”, ,Jupiter, Jovis, g.m. văzduh, aer; iarăş: fiiul lui Saturnus pre care l-au țînut poeticii prea de sus a fi”, „Tantalus, g.m. fiul lui Iupiter şi al Plutei, carele în iad (din părearea poeticilor) totodeuna însătează şi flamînzeaşte, săvai că pînă la grumaz stă în apă şi înaintea nasului spînzură mărul cel rodit, cu care, cînd va să trăiască, îndată să zmuceaşte de la dîns; hinc: tantalus, -a, -um” etc.

${ }^{18}$ „Rhadamanthus, g.m. fiiul lui Iupiter şi al Europei, derept şi vîrtos împărat al Liției, de unde poeticii îl țîn a fi împărat sufletelor din iad”, „Cunina, g.f. bătrînii o au țînut a fi dumnezăoaie a copiilor înțelepți”, „Atropos, g.f. nepurcegătoare, adecă una dintru 3 parche, carele fieştecăruia de la dumnezău svîrşită viiaţă croiescu, (jerebiia) tortul îl taie. Bătrînii cei de demult precum au fost romanii şi elinii pre aceastea mai sus zise le-au numit a fi dumnezăoaie”, „daps, g.f. feali al jîrtvei au fost la cei de demult”, „Druidæx, g.m. pl. înțelepții cei de demult ai frîncilor”, „lucuus, g.m. nume de bucate au fost la cei de demult”, „Marica dumnezău l-au ținut cei de demult a fi purtători de grija țărmurilor”, „Opigema, g.f. Iuno, pre care cei de demult o au socotit ajutătoare copiilor celor ce să nasc”, „Tænarus, g.m. pl. Tænara, g.n. un deal aproape de Spartha sau un loc sub dealul Malca unde iaste o groapă mare şi o peştere adîncă, îmbăsnată, care cei de demult o au socotit poarta iadului” etc. Marcarea receptăririi culturale a mitologiei antice este subliniată şi de faptul că nu rareori sînt citați şi autorii în scrierile cărora se află menționate informații referitoare la aceasta: „Tutilina, g.f. Varro et Nonius dumnezăiță s-au țînut a scutirei, a ferirei la romanii cei de demult" etc.

${ }^{19}$ „liber, libri, g.m. pelița cea supțîre albă dinlăuntru a coajei lemnului pre care au scris cei de demult (adecă bătrînii)”, „albegnnina, g.n. pl. partea cea albă a mațelor vitelor, care dumnezăilor au jîrvuit cei de demult”, „amystis, g.f. neamul băuturei de duşcă au fost la sîrbii cei de demult”, „daps, g.f. feali al jîrtvei au fost la cei de demult”, „Hunni, g.m. pl. ungurii cei de demult”, ,jazyges, g.m. pl. lăcuitorii cei de demult ai T,ărei Ardealului”, „lucuus, g.m. nume de bucate au fost la cei de demult”, „Marcomani, g.m. pl. cechii şi morăvanii cei de demult”, „Metanastæ, g.m. pl. ardeleanii, lăcuitorii cei de demult ai Ardealului”, „myxon, g.m. feali al peaştelui pre care romanii cei de demult bucată mare l-au țînut a fi”, „phalæ, g.f. pl. turn de lemn care cei de demult l-au zidit în locul de privirea jocului”, „philura, g.f. coaja cea dinlăuntru a teiului, pă care au scris cei de demult”, „rogus, -i, g.m. grămadă de leamne pă care cei de demult au ars trupurile ceale moarte”. 
Cetății Eterne evocau două universuri diferite. Acest fapt este un semn evident al procesului de laicizare a culturii române, cînd culturalul şi religiosul nu mai coincid ${ }^{20}$, cele două lumi evocînd spații diferite.

4.9. Dacă Italia și Grecia sînt cunoscute mai ales din perspectiva informațiilor culese din literatura grecolatină, Europa (Franța și Germania în special) este prezentă prin informații pertinente ale timpului modern; astfel, centrul lumii devine orașul Nürenberg: „Noriberga, g.m. oraș mare al Țărei Nemțești, care cu frumoasa zidire, cu bogățiia, cu neguțători, cu fealiuri de fealiuri de lucruri scumpe și cu oameni meșteri iaste vestit și nu o mint. Acesta, în toată Evropa, în Țara Nemțască alte orașuri biruind, cu Vinețiia frîncească [sic!] să priceaşte. Acest oraș nu numai Țărei Nemţăști ci şi toții Evrope în mijloc iaste” sau „Norvegia, g.f. țînutul Evropei de cătră crivăț, care îl biruiaşte craiul danienesc”.

4.10. Reperele lumii moderne sînt în primul rînd cele culturale: „Argentina, g.f. et Argentoratum tare oraş al Țărei Nemțești lîngă apa Rhenus, în țînutul Alsației. Acolo ca acela înalt turn iaste și bisearecă înfrîmșețată, cît în Europa altă bisearică sau turn aseamine acestora nu iaste. Iaste iarăş acolo o academie vestită, în care de demult mulți înțelepți oameni s-au învățat”, „Altorsium, g.n. orășăl în țînutul domnilor norimbergheani, în care acest noriberghean svat cinsteș bogată academie au zidit în numărul anilor 1575", „Herbona, g.f. oraș în țînutul Nasoviei al Țării Nemțăști, în care iaste școală vestită, care să priceaște cu academiile și pre care le și învince”, „Marpurgum oraș al Țărei Nemțești în țînutul Hassiei în care iaste academie vestită”. Informațiile referitoare la cultura ulterioară Antichității sînt sporadice: se înregistrează, printre altele, numele Venerabilului Beda („Beda, g.m. în Țara Angliei au fost dascal învăţător de Scriptura Svîntă”) sau cel al compozitorului Orlando di Lasso („Lasus, g.m. cel mai dintîi care au scris de muzică”); despre Boccaccio cunoaște doar activitatea istoriografică: „Boccatius, g.m. un istoriceari italiian".

Orizontul umanist al lui Teodor Corbea se exprimă, la fel ca în cazul altor contemporani ai săi, susținînd ideea latinităţii limbii, constatată de mulți oameni de cultură occidentali care au avut contact cu românii, afirmată și de istoriografia română începînd cu secolul al XVII-lea (Grigore Ureche, Miron Costin, Stolnicul Constantin Cantacuzino, Dimitrie Cantemir etc.). Spre deosebire de aceștia, Teodor Corbea nu o afirmă direct, nevorbind explicit, ca ceilalți cărturari, despre descendența romană a poporului său. Identificînd în mod curent vechile populaţii din Antichitate cu cei care locuiau în timpul său regiunea respectivă, el face această extrapolare și în cadrul spațiului românesc: „Daci, g.m. pl. rumînii”, „Getæ, g.m. pl. rumînii”, „geticus, -a, -um rumînesc, -ă, din Țara Rumînească”, cu toate că aceleiași populații i se face și o altă identificare: „Dacæ, g.m. pl. seminții de la Sțithiia”.

\section{Influenţa modelului latinesc}

El este, însă, evident conștient de originea latină a unor cuvinte românești. Numeroase paralelisme între latină și română îl fac să alcătuiască o listă considerabil îmbogățită față de cele făcute înaintea lui de Grigore Ureche și Miron Costin, fapt care dovedește o conștiință evidentă a romanităţii. Citînd doar din primele pagini ale dicționarului, găsim: „abellina, g.f. alună”, „abjugo, -as dezjug”, ,abjuratio jurare”, „abnepos, g.m. strănepot”, „abneptis, g.f. strănepoată”, „abnodo, -as clinciurile, nodurile curăț”, „abrodo, -is, -ere roz”, „abrumpo, -is, -ere rumpu”, „abscondo, -is, -ere ascunz, tăinuiesc”, „absconsio, -onis ascundere”, „absconsor, g.m. ascunzători”, „absimilis, -e usebit, -ă, nu-aseamine”, „absisto, -is, -ere stau, las”, „absorbeo, -es, -bui, -psi sorbu”, „abstergeo, -es, -ere ștergu”, „abstersio, g.f. șteargere”, „abstersus, -a, -um șters, -ă”, ,,accresco, -is, -ere cresc”, ,acer, acris et acra acru”, ,acor, g.m. înăcrime”, „acor, g.m. înăcrime”, „acuncula, - $x$, g.f. acșor”, ,acus, -us, g.f. ac”, ,adaquo, -as vite adăp”, , ,addenseo, -es desăsc”, ,addesso, -es desăsc”, ,adductio, g.f. ducere, povățuire spre ceva”, „adfringo, -is frîngu”, „adgemo, -is gemu”, „ajuro, -as foarte mă juru”, „ajuto, -as ajutu”, „adjutor ajutători”, „adjutorium ajutori”, „adjutrix ajutătoare”, „adjutus, -a, -um ajutat, -ă”, „adjuvo, -as ajutu”, ,adlatro, -as latru”,

\footnotetext{
${ }^{20}$ Pentru cultura românească anterioară putem urmări cum religiosul, dominant, producea o selecție a valorilor în funcție de nevoile sale.
} 
„admiratio, g.f. minune, ciudă, mirare”, „admirator, m. minunători, mirători”, „admiror, -aris mă mir, mă minunez”, „admugio, -is, -ire zbieru, mugescu”, „adporto, -as portu, aducu”, „adrado, -is razu”, „adrodo, -is rozu”, „adsideo, -es, -ere șezu lîngă ceva”, „adsido, -is așezu lîngă ceva, mă sloboz”, „arma, g.f. armă”, ,armus, g.m. armă, umere”, ,arquatus, -a, -um în chipul arcului plecat, strîmb, -ă”, ,arquites, g.m. pl. arcari, războitori cu arce”, ,arquus, g.m. arc” etc.

5.1. În situația în care limba maghiară nu cunoaște la adjective genul, Corbea urmează în echivalentele românești modelul limbii latine și în ceea ce privește această categorie gramaticală: „affirmatus, -a, -um

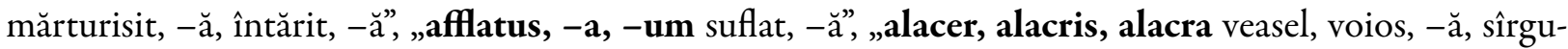
itori, -re, isteț, -ță, ager, -ră”, „algidus, -a, -um friguros, -ă, geros, -ă”, ,algificus, -a, -um friguitori, -re, geruitori, -re” etc. Uneori, pentru a sublinia existența genurilor, folosește expresia „pă 3 neamuri”: „æxdonius, -a, -um trațienesc, -ă; iarăş: de preveghitoare (pă 3 neamuri)”, „æneus, -a, -um de aramă (pă 3 neamuri)”, „æquanimus, -a, -um cu inimă lină (pă 3 neamuri)”, „æedilitius, -a, -um spre boieriia ziditoriului meşter lucru sau altceva (şi aşa pă trei neamuri)” etc., menționînd variabilitatea formelor adjectivale chiar şi atunci cînd, în cazul expresiilor perifrastice, ea nu se realizează în concret în limba română: „acernus, -a, -um de arțari (pă trei neamuri)”, „ædonius, -a, -um traţienesc, -ă; iarăș: de preveghitoare (pă 3 neamuri)", „ærius, -a, -um văzduhos, -ă, de aer (pă 3 neamuri)”, ,affinis, -e vecin, -ă, de aproape (pă 3 neamuri)”, „æquævus, -a, -um de o vreame (pă trei neamuri)”, ,ætnæus, -a, -um din muntele Siliției (floare) și așa umblă pă trei neamuri”. Conștient de asemănarea cu limba latină și, implicit, deosebirea de limba maghiară, el notează: „æetolus, -a, -um de la Etoliia om sau altceva, fieștece neam va hi (pentru că așa umblă la rumîni acest feali de nume adăogători)". Diferența dintre latină și română îl conduc uneori la precizări ca: „dimidius, -a, -um jumătate (pă 2 neamuri rumînești)”.

5.2. Lexicul latin al dicționarului a făcut ca autorul să apeleze în echivalarea românească, în mod conștient, la lexicul românesc care descinde din respectivul etimon, chiar dacă acele cuvinte sînt rare. O astfel de situație o găsim în cazul verbului mursăca, folosit doar în legătură cu verbul latinesc morsicare: „morsicatim, adv. mușcățeaște, mursăcățeaște”, „morsio, g.f. mușcare, mursăcare”, „morsiuncula, g.f. mușcăturea, mursăcăturea”, „morsus, -us, g.m. mușcare, mursăcatul”, „morsus, -a, -um mușcat, -ă, mursăcat, -ă”; în restul dicționarului, Teodor Corbea folosește a muşca, chiar și în situația în care avem prefixări ale lui mordere: „admordeo, -es mușcu”, ,commordeo, -as mușcu”, ,demordeo, -es mușcu jos”, „mordax, -cis, g.o. mușcători, -re, usturători, -re, pișcători”, „mordacitas, g.f. mușcătură, pișcătură”, „mordeo, -as mușcu”, „mordicibus pro morsibus, dixit Plautus cu mușcători”, „mordico, -as mușcătorescu”, „mordicus, adv. mușcînd, mușcățeaște”. Conștiința latinității limbii se manifestă și prin apelarea la unele cuvinte regionale rare, sugerate de cuvîntul latinesc, motiv pentru care simte nevoia unei explicații suplimentare: „colostra, g.f. corastră, laptele cel dintîi după naștere”. Corbea efectuează chiar și refacerea unor forme după modelul textului latin, mai apropiate fonetic de cuvintul latin, de exemplu capestere („capisterium, g.n. capesteare, ciur”), în situația în care în restul dicționarului se folosește căpestere: „labrum, g.n. buză; iarăș: scafă, căpestere, troacă”, „mactra, g.f. moldă, căpesteare de copt, căpesteare de frămîntat”, „magis, -dis, g.f. moldă, căpesteare de frămîntat” etc.

\section{Concluzii}

La întrebarea pe care, firește, ne-o punem, și anume în ce scop episcopul Mitrofan al Buzăului a avut nevoie de acest dicționar, avem mai multe răspunsuri, toate la fel de valabile. Mitrofan, fost episcop de Huși și colaborator al mitropolitului Dosoftei și, după venirea sa în Țara Românească, implicat în tipărirea Bibliei de la București, era un om de aleasă cultură, pentru care accesul la textele redactate în limba latină era foarte important. În mod special, însă, era important accesul la cea mai mare culegere latină a vieților sfinților, Vita sanctorum, pe care a folosit-o în tipărirea Mineiului de la 1698. Și, dacă o simplă apropiere de limbă poate justifica identificarea unui scriitor, formularea cici și colea pentru „aici și acolo”, pe care o găsim în textele epocii doar în dicționarul lui Teodor Corbea și în unele vieți ale sfinților din Mineiul de la Buzău, 
ne îndreptățește să bănuim că acesta a fost nu doar un simplu traducător plătit al dicționarului, ci și un colaborator al monumentalei lucrări a Mineiului.

\section{Bibliografie}

DUL = Albert Szenczi Molnár, Dictionarium Ungarico-Latinum, Heidelberg, 1621.

Gherman, A.-M. (2001). Cele două Rome ale lui Teodor Corbea, în „Romania Orientale”, XIV, Bagatto Libri, Roma, p. 125141.

Gherman, A.-M. (2019). Studiu introductiv la Ioan Zoba din Vinț, Cărare pre scurt, Muzeul Național al Unirii, Alba Iulia.

Pippidi, A. (2005). Noi mărturii despre relațiile lui Rákóczi cu românii, în „Studii şi materiale de istorie medie”, XXIII, p. 281300.

Vocab. 1840-1841 = P. Poenaru, F. Aaron, G. Hill, Vocabular franțezo-românesc după cea din urmă ediție a dicționarului de Academia Franțozească, tom. 1-2, Tipografia Colegiului „Sfîntul Sava”, București, 1840-1841.

Seche, M. (1966). Schiță de istorie a lexicografiei românești, vol. I-II, Editura Științifică, București.

TLG = Henricus Stephanus, Thesaurus grace lingue, Paris, 1572. 